\title{
Metabolic and Hormonal Responses to Oral Amino Acids in Infantile Malnutrition
}

\author{
R. D. G. MILNER \\ From Medical Research Council, Tropical Metabolism Research Unit, University of the West Indies, \\ Jamaica
}

\begin{abstract}
Milner, R. D. G. (1971). Archives of Disease in Childhood, 46, 301. Metabolic and hormonal responses to oral amino acids in infantile malnutrition. A mixture of 10 essential amino acids was given by gavage to 8 children with infantile malnutrition and 7 children who had clinically recovered from malnutrition. Blood samples taken before and at different times after the amino acid load were analysed for glucose, free fatty acid, $\alpha$-amino nitrogen, insulin, and growth hormone. In both the malnourished and the recovered children the amino acid load caused a rise in plasma $\alpha$-amino nitrogen and glucose, and a fall in growth hormone levels, but no change in plasma free fatty acid or insulin levels.
\end{abstract}

Malnutrition in man causes disturbances of endocrine function (see review by Milner, 1970). In particular plasma growth hormone $(\mathrm{GH})$ levels are raised in infantile malnutrition (Pimstone et al., 1966, 1967, 1968a) while insulin levels are low (Baig and Edozien, 1965; Hadden, 1967). Glucagon causes a further rise in GH levels (Milner, 1971) while hyperglycaemia results in a sluggish fall (Pimstone et al., 1967) There is a subnormal insulin response to a glucose challenge in the malnourished child, both initially (Baig and Edozien, 1965; Hadden, 1967) and after clinical recovery (James and Coore, 1970; Milner, 1971). Glucose is not the only metabolite to influence plasma levels of these two hormones however. Recent studies have shown that oral protein or intravenous amino acids are potent stimuli of insulin and growth hormone secretion (Floyd et al., 1966a, b; Knopf et al., 1965). It has been suggested that the sequential rise of insulin and growth hormone after oral protein leads to synergism of the anabolic roles of these hormones (Rabinowitz et al., 1966). This form of stimulus was therefore chosen to investigate further the interrelationships of insulin, growth hormone, and various metabolites in the malnourished infant on admission to hospital, and after clinical recovery.

\section{Patients and Methods}

The children studied were patients admitted to the Unit for the investigation and treatment of infantile

Received 7 December 1970. malnutrition. The nature of the investigation was explained carefully to the parent or guardian at the time of admission and written consent was obtained. The classification of clinical malnutrition was based on two objective criteria (Lancet, 1970): weight and oedema. Of the 15 patients studied, 4 had oedema and were less than $60 \%$ of the 50 th centile for weight (Nelson, 1959); they may be described as having marasmic-kwashiorkor, and form the commonest type of malnourished child admitted to the Unit; 5 had marasmus, i.e. they were less than $60 \%$ of their expected weight, but had no oedema; 4 had oedema, and were more than $60 \%$ of their expected weight: they had kwashiorkor. 2 were 61 and $66 \%$ of their expected weight but had no oedema; they are described as undernourished. Clinical details of the 8 patients studied shortly after admission and the 7 studied after clinical recovery are given in Table $I$. As previous studies (Alleyne and Scullard, 1970) had not revealed characteristic metabolic differences between the clinical groups seen in Jamaica, no distinction was made on the basis of clinical classification. Each child was treated with milk feeds of increasing strength and for most of his stay received approximately 150 calories and $3 \mathrm{~g}$ protein $/ \mathrm{kg}$ body weight per day. Folic acid, ferrous sulphate, and vitamin supplements were given routinely; infection was treated when present.

Blood samples were collected by venepuncture after an overnight fast $(8-9 \mathrm{hr})$ at various times. A nasogastric tube was passed approximately one hour before the first blood sample was withdrawn. After collection of the initial sample, a mixture $(0.5 \mathrm{~g} / \mathrm{kg}$ body weight) of the 10 essential amino acids (Sigma Chemical Co., St. Louis, Mo., U.S.A.) prepared as described by Floyd et al. (1966b), was given via the tube. Further blood samples were withdrawn 15, 30, 60, 120, and 180 minutes afterwards. 
TABLE I

Clinical Features of 15 Children with Infantile Malnutrition

\begin{tabular}{|c|c|c|c|c|c|c|}
\hline \multirow{2}{*}{ Case No. and Sex } & \multicolumn{3}{|c|}{ On Admission } & \multirow{2}{*}{ Diagnosis } & \multirow{2}{*}{$\mathbf{E W A} \star(\%)$} & \multirow{2}{*}{$\begin{array}{l}\text { Days From } \\
\text { Admission to } \\
\text { Time of Study }\end{array}$} \\
\hline & Age (mth) & Weight (kg) & Oedema & & & \\
\hline 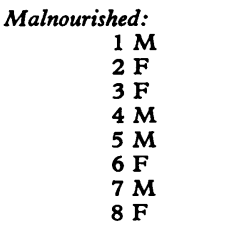 & $\begin{array}{r}10 \\
9 \\
10 \\
9 \\
22 \\
12 \\
13 \\
8\end{array}$ & $\begin{array}{l}4 \cdot 27 \\
6 \cdot 31 \\
5 \cdot 52 \\
3 \cdot 94 \\
6 \cdot 20 \\
6 \cdot 83 \\
7 \cdot 30 \\
5 \cdot 37\end{array}$ & $\begin{array}{l}+ \\
++ \\
- \\
- \\
++ \\
++ \\
-\end{array}$ & $\begin{array}{l}\text { Marasmic-kwashiorkor } \\
\text { Kwashiorkor } \\
\text { Undernourished } \\
\text { Marasmus } \\
\text { Marasmic-kwashiorkor } \\
\text { Kwashiorkor } \\
\text { Kwashiorkor } \\
\text { Undernourished }\end{array}$ & $\begin{array}{l}43 \\
72 \\
61 \\
43 \\
51 \\
70 \\
73 \\
66\end{array}$ & $\begin{array}{r}15 \\
21 \\
11 \\
12 \\
17 \\
1 \\
1 \\
4\end{array}$ \\
\hline $\begin{array}{rl}\text { Recovered: } & \\
9 & \mathrm{M} \\
10 \mathrm{~F} \\
11 \mathrm{~F} \\
12 \mathrm{M} \\
13 \mathrm{M} \\
14 \mathrm{M} \\
15 \mathrm{M}\end{array}$ & $\begin{array}{r}9 \\
16 \\
9 \\
13 \\
11 \\
12 \\
9\end{array}$ & $\begin{array}{l}4 \cdot 25 \\
6 \cdot 76 \\
3 \cdot 86 \\
4 \cdot 46 \\
3 \cdot 86 \\
5 \cdot 75 \\
3 \cdot 36\end{array}$ & $\begin{array}{l}- \\
+ \\
+ \\
+ \\
-+\end{array}$ & $\begin{array}{l}\text { Marasmus } \\
\text { Kwashiorkor } \\
\text { Marasmus } \\
\text { Marasmic-kwashiorkor } \\
\text { Marasmic } \\
\text { Marasmic-kwashiorkor } \\
\text { Marasmus }\end{array}$ & $\begin{array}{l}47 \\
64 \\
44 \\
43 \\
40 \\
57 \\
37\end{array}$ & $\begin{array}{l}75 \\
63 \\
80 \\
80 \\
72 \\
83 \\
98\end{array}$ \\
\hline
\end{tabular}

^ EWA $=$ Expected weight for age, by comparison with the 50th centile (Nelson, 1959).

All blood samples were collected into bottles containing heparin and fluoride and were centrifuged within 30 minutes. Plasma glucose and free fatty acid (FFA) levels were estimated the same day. Aliquots of plasma were stored at $-20^{\circ} \mathrm{C}$ until $\alpha$-amino nitrogen, insulin, and GH levels were measured. $300 \mu$ l plasma sufficed for duplicate determinations of glucose, FFA, $\alpha$-amino nitrogen, insulin, and $\mathrm{GH}$, thus making feasible repeated blood samples on one infant on one day. Plasma glucose was determined by a glucose oxidase assay (Huggett and Nixon, 1957), FFA by a modification (Shelley and Thalme, 1970) of the method of Novák (1965), and $\alpha$-amino nitrogen by the method of Stein and Moore (1954). Plasma insulin was measured by immunoassay (Hales and Randle, 1963) using an ox insulin standard and an antibody which did not discriminate between ox and human insulin (kindly given by Dr. B. A. L. Hurn of the Wellcome Laboratories, Beckenham, England). Plasma GH was measured by immunoassay using pre-precipitated antibody, filtration for the separation of 'free' and 'bound' hormone and a human GH standard (M.R.C. new preparation R4 kindly given by Dr. A. Stockell-Hartree, Department of Biochemistry, University of Cambridge). Standard GH solutions and plasma diluted in parallel in the assay. Statistical analyses were done by Students $t$ test.

\section{Results}

The results of the investigations are presented in Table II and the mean values for plasma $\alpha$-amino nitrogen glucose, insulin, and $\mathrm{GH}$ are plotted against time in the Fig. The fasting levels of glucose, FFA, and $\alpha$-amino nitrogen were similar in the two groups. The fasting plasma insulin level was significantly lower in the malnourished group. The $\mathrm{GH}$ level was higher but the difference between the malnourished and recovered groups was not significant because of the wide range of individual values. The administration of amino acids via a stomach tube caused a similar rise in $\alpha$-amino nitrogen in both the malnourished and recovered infants, which was maximum at 60 minutes. This was associated with a modest rise in plasma glucose levels, the difference between the 60 - and 0 -minute value being significant in both the malnourished and recovered babies. No significant change occurred in FFA or insulin levels after the amino acid load. There was no significant difference between the plasma GH levels in the malnourished and recovered groups at any time though the mean levels in the recovered group were approximately half those in the malnourished group throughout the test. In both groups there was a significant and similar fall in plasma $\mathrm{GH}$ after the ingestion of amino acids. The fall occurred in 30 minutes and thereafter the plasma $\mathrm{GH}$ level remained steady.

\section{Discussion}

Oral amino acids given to malnourished children shortly after admission to hospital or after clinical recovery caused no change in plasma insulin levels, and a fall in plasma growth hormone levels. The importance of these findings lies in the fact that they are qualitatively different from those predicted on the basis of studies in the normal adult. 


\section{TABLE II}

Plasma Glucose, FFA, $\alpha$-Amino Nitrogen, Insulin, and GH Responses to Intragastric Amino Acids in Malnourished Children Before and After Recovery

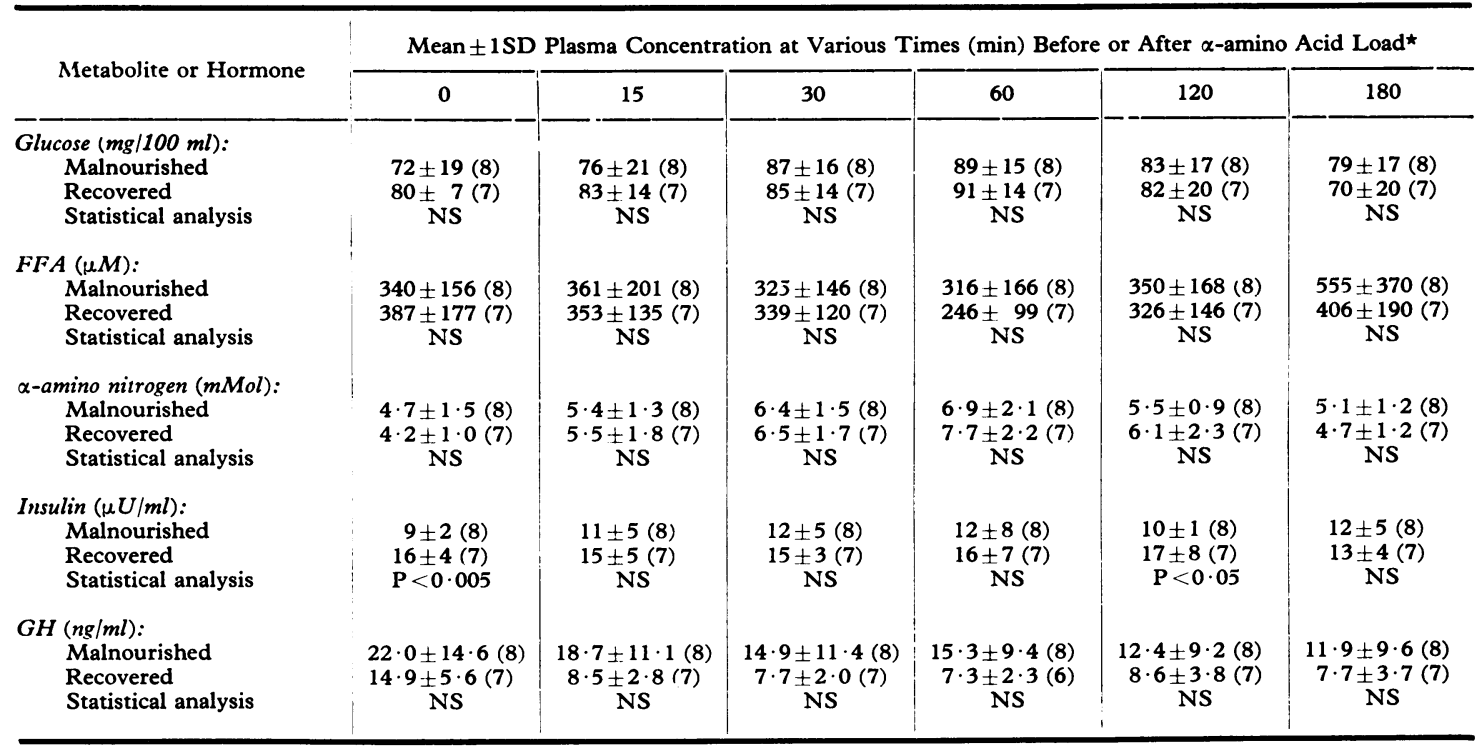

^ Number of observations in parentheses.
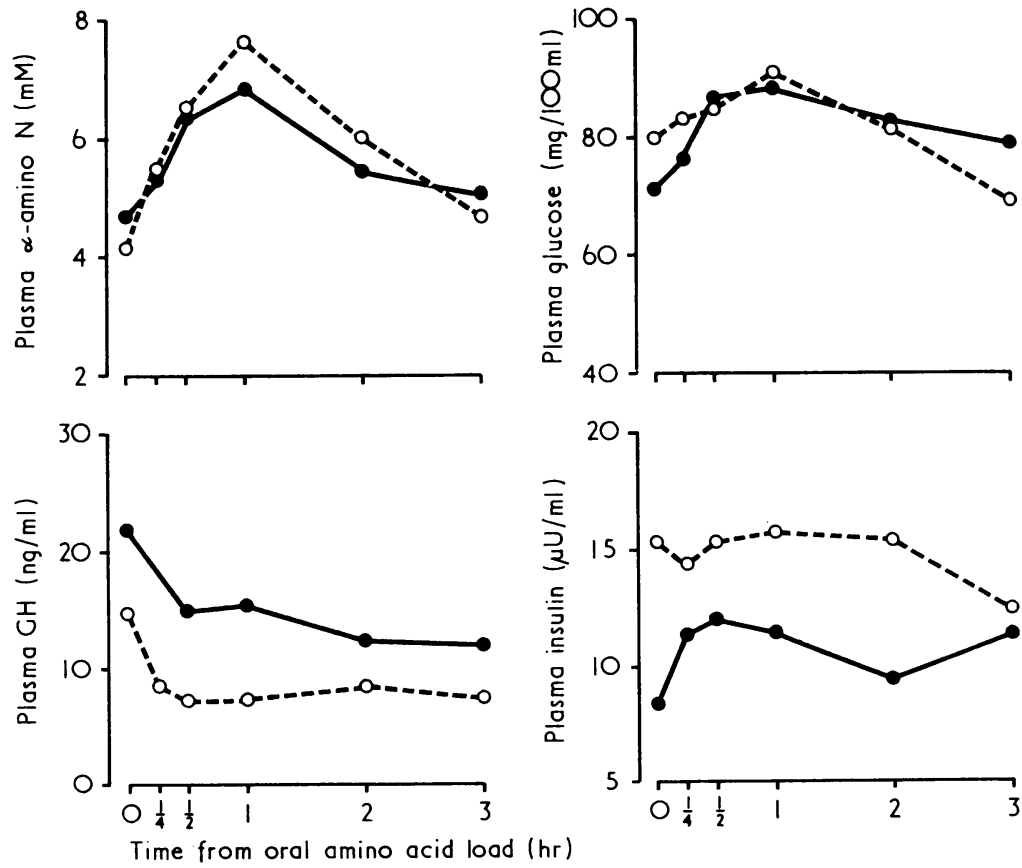

FIG.-Mean values of plasma $\alpha$-amino nitrogen, glucose, insulin, and $G H$ before ( 0 min) and at various times after the administration of a mixture of the 10 essential amino acids via a nasogastric tube to malnourished infants shortly after admission to hospital (closed circles) or after clinical recovery (open circles). 
The amino acid load was given by gavage as a compromise between giving oral protein or intravenous amino acids, since the digestion and absorption of foodstuffs is known to be impaired in infantile malnutrition and it was not known if the intravenous administration of amino acids to small infants would have adverse side effects. The compromise was shown to be valid by the rise in plasma $\alpha$-amino nitrogen levels. The qualitative similarity of the response of the sick and recovered group to the amino acid load may reflect the fact that though the sick group was physically malnourished, their metabolic responses might reflect more the current food intake than the chronic nutritional deprivation. For example, the lack of difference in the fasting plasma FFA values in the two groups is probably due to the fact that the malnourished group was studied up to 21 days after admission to hospital. Some of these infants had very high FFA values during the first three days of admission (Milner, 1971) but these fell rapidly to normal on resumption of a high caloric intake.

The failure of the amino acid challenge to cause a rise in plasma insulin levels is in keeping with the recent observations that $\beta$ cell function remains impaired after clinical recovery from malnutrition (James and Coore, 1970; Milner, 1971). Insulin release is influenced by enteric hormones (Dupré et al., 1969), and disordered gastrointestinal function which occurs in malnutrition may be a contributory factor to subnormal insulin secretion.

Caution must be exercised in making a causal relation between the rise in plasma $\alpha$-amino nitrogen and the fall in plasma GH levels. It is possible that the passage of a nasogastric tube some 60 minutes before the start of the test was a sufficient non-specific stress to cause a spurious increase in the fasting $\mathrm{GH}$ values. Against this idea is the fact that fasting $\mathrm{GH}$ values in similar malnourished infants who did not have a nasogastric tube were similar to those in the present study (Milner, 1971). Also the stress of repeated venepunctures in such infants is known to cause a rise in plasma $\mathrm{GH}$ of about $10 \mathrm{ng} / \mathrm{ml}$ on the third venepucture at 10 minutes, which disappears by 30 minutes (Milner, 1971). Thus if passing the nasogastric tube had been stressful, it was anticipated that the GH response would have faded by the time sample collection started. If the venepunctures themselves caused a rise in plasma GH this would lessen the true fall in plasma GH occurring in association with the amino acid load.

The reason for the raised plasma GH levels in infantile malnutrition is not clear. Pimstone et al. (1968a) suggested that the fall in GH with recovery was causally associated with the rise in plasma albumin concentration, but were unable to influence plasma GH levels in the malnourished child by albumin infusions (Pimstone et al., 1968b). If a direct relation between plasma $\mathrm{GH}$ levels and protein metabolism does exist, it may be between GH and an amino acid or acids rather than between GH and a protein. The results of the present study would be compatible with a scheme whereby amino acids have a direct feedback control on GH release analogous to that postulated for glucose in the adult. The results provide no clue, however, as to whether the changes in plasma $\mathrm{GH}$ after an oral amino acid load are a characteristic of malnutrition, of infancy, or more particularly of nutrition in infants.

I wish to thank Professor J. C. Waterlow, Director of the MRC Tropical Metabolism Research Unit, for his encouragement throughout these investigations and Miss M. Ceballos for technical assistance.

\section{REFERENCES}

Alleyne, G. A. O., and Scullard, G. H. (1970). Alterations in carbohydrate metabolism in Jamaican children with severe malnutrition. Clinical Science, 37, 631.

Baig, H. A., and Edozien, J. C. (1965). Carbohydrate metabolism in kwashiorkor. Lancet, 2, 662.

Dupré, J., Curtis, J. D., Unger, R. H., Waddell, R. W., and Beck, J. C. (1969). Effects of secretin, pancreozymin or gastrin on the response of the endocrine pancreas to administration of glucose or arginine in man. Fournal of Clinical Investigation, 48, 745 .

Floyd, J. C., Jr., Fajans, S. S., Conn, J. W., Knopf, R. F., and Rull, J. (1966a). Insulin secretion in response to protein ingestion. Fournal of Clinical Investigation, 45, 1479.

Floyd, J. C., Jr., Fajans, S. S., Conn, J. W., Knopf, R. F., and Rull, J. (1966b). Stimulation of insulin secretion by amino acids. Fournal of Clinical Investigation, 45, 1487.

Hadden, D. R. (1967). Glucose, free fatty acid, and insulin interrelations in kwashiorkor and marasmus. Lancet, 2, 589.

Hales, C. N., and Randle, P. J. (1963). Immunoassay of insulin with insulin-antibody precipitate. Biochemical fournal, 88, 137.

Huggett, A. St. G., and Nixon, D. A. (1957). Use of glucose oxidase, peroxidase, and o-dianisidine in determination of blood and urinary glucose. Lancet, 2, 368.

James, W. P. T., and Coore, H. G. (1970). Persistent impairment of insulin secretion and of glucose tolerance after malnutrition. American Fournal of Clinical Nutrition, 23, 386.

Knopf, R. F., Conn, J. W., Fajans, S. S., Floyd, J. C., Guntsche, E. M., and Rull, J. A. (1965). Plasma growth hormone response to intravenous administration of amino acids. Fournal of Clinical Endocrinology, 25, 1140.

Lancet (1970). Classification of infantile malnutrition, 2, 302.

Milner, R. D. G. (1970). Malnutrition and the endocrine system in man. In Hormones and the Environment, p. 191. Ed. by G. K. Benson and J. G. Phillips. Cambridge University Press, London.

Milner, R. D. G. (1971). Metabolic and hormonal responses to glucose and glucagon in infantile malnutrition. Pediatric Research, 5, 33.

Nelson, W. E. (1959). Textbook of Pediatrics, 7th ed., p. 51. Saunders, Philadelphia.

Novák, M. (1965). Colorimetric ultramicro method for the determination of free fatty acids. Fournal of Lipid Research, 6, 431.

Pimstone, B. L., Barbezat, G., Hansen, J. D. L., and Murray, P. (1967). Growth hormone and protein-calorie malnutrition: impaired suppression during induced hyperglycaemia. Lancet, 2, 1333. 
Pimstone, B. L., Barbezat, G., Hansen, J. D. L., and Murray, P. (1968a). Studies on growth hormone secretion in proteincalorie malnutrition. American fournal of Clinical Nutrition: 21, 482.

Pimstone, B. L., Saunders, S. J., Hansen, J. D. L., and BuchananLee, B. (1968b). In Symposium on Protein and Polypeptide Hormones, vol. 3, p. 906 . Ed. by M. Margoulies. Excerpta Medica Foundation, Amsterdam.

Pimstone, B. L., Wittmann, W., Hansen, J. D. L., and Murray, P. (1966). Growth hormone and kwashiorkor. Role of protein in growth-hormone homoeostasis. Lancet, 2, 779.

Rabinowitz, D., Merimee, T. J., Maffezoli, R., and Burgess, J. A. (1966). Patterns of hormonal release after glucose, protein, and glucose plus protein. Lancet, 2, 454.
Shelley, H. J., and Thalme, B. (1970). Some aspects of lipid and carbohydrate metabolism in foetal and newborn rabbits. In Stoffwechsel des Neugeborenen, p. 178. Ed. by G. Joppich and H. Wolf. Hippocrates-Verlag, Stuttgart.

Stein, W. H., and Moore, S. (1954). The free amino acids of human blood plasma. Fournal of Biological Chemistry, 211, 915.

Correspondence to Dr. R. D. G. Milner, Department of Child Health, University of Manchester, St. Mary's Hospital, Manchester 13. 